Tersedia online di: http://ejournal-balitbang.kkp.go.id/index.php/jra

\title{
PENINGKATAN PERTUMBUHAN DAN SINTASAN BENIH IKAN TUNA SIRIP KUNING, Thunnus albacares DALAM PENDEDERAN SISTEM INDOOR
}

\author{
Jhon Harianto Hutapea\#, Ananto Setiadi, dan Gunawan
}

Balai Besar Riset Budidaya Laut dan Penyuluhan Perikanan

Jl. Br. Gondol, Kec. Gerokgak Kab. Buleleng, Po. Box 140, Singaraja, Bali 81101

(Naskah diterima: 27 November 2020; Revisi final: 17 Maret 2021; Disetujui publikasi: 18 Maret 2021)

\begin{abstract}
ABSTRAK
Sintasan larva hingga benih ikan tuna sirip kuning di hatchery sudah meningkat dari $0,05 \%$ menjadi $0,20 \%$ 0,50\% Namun mortalitas pada pemeliharaan tahap berikutnya sangat tinggi. Kematian benih karena menabrak dinding bak/jaring, berkaitan dengan kebiasaan renang dan kondisi lingkungan. Oleh karena itu, riset pendederan ini difokuskan pada pengamatan kebiasaan berenang dan pemangsaan, serta kondisi lingkungan. Wadah yang digunakan adalah enam buah bak fiberglass reinforced plastic (FRP) diameter 2,7 m; ketinggian 1,0 m; dan diisi dengan air laut $5 \mathrm{~m}^{3}$. Hewan uji berupa benih ikan tuna sirip kuning dengan panjang total 29,82 $\pm 2,51 \mathrm{~mm}$ hasil produksi dari hatchery, sebanyak 50 ekor benih per bak. Perlakuan dalam riset adalah perbedaan sistem pemeliharaan, yaitu: (A) indoor dan (B) outdoor dengan tiga ulangan dan lama penelitian 21 hari. Pakan yang digunakan adalah ikan segar berupa benih bandeng yang dimatikan dan ikan teri dengan panjang total $15-25 \mathrm{~mm}$ dan ikan cincang (minced fish). Frekuensi pemberian pakan adalah enam kali per hari dan diberikan secara satiasi. Parameter meliputi suhu, oksigen terlarut, dan intensitas cahaya diukur setiap hari. Hasil riset menunjukkan bahwa sintasan dalam pendederan sistem indoor sebesar $20,0 \pm 4,0 \%$ lebih tinggi $(P<0,05)$ dibanding dengan sistem outdoor $(6,7 \pm 5,0 \%$ ). Pertumbuhan bobot spesifik $12,4 \%$ hari $^{-1}$ pada sistem indoor lebih baik dibandingkan sistem outdoor yang hanya $9,8 \%$ hari $^{-1}(P<0,05)$. Dari hasil penelitian ini dapat disimpulkan bahwa intensitas cahaya dan suhu yang lebih stabil pada pendederan sistem indoor memberikan sintasan dan pertumbuhan yang lebih baik dibandingkan pada sistem outdoor. Namun demikian, disarankan bahwa pendederan dalam bak FRP sebaiknya tidak lebih dari dua minggu agar diperoleh sintasan yang lebih tinggi dan selanjutnya dipindahkan ke karamba jaring apung (KJA).
\end{abstract}

KATA KUNCI: benih; bak; indoor; outdoor; pendederan; tuna sirip kuning

ABSTRACT: Improvement of growth and survival rate of yellowfin tuna Thunnus albacares juvenile in indoor nursery system. By: Jhon Harianto Hutapea, Ananto Setiadi, and Gunawan

The survival rate of reared yellowfin tuna from larvae to juvenile stages in hatchery has been improved from $0.05 \%$ to $0.20 \% 0.50 \%$ Unfortunately, the fish's mortality rate during the nursery phase is still very high. Unpredicted swimming and feeding behaviors have resulted the reared juveniles to uncontrollably hit the tank wall and died. Therefore, this research was carried out to study the swimming and feeding habits of yellowfin tuna juveniles and its response to different rearing environments. Six fiberglass reinforced plastic (FRP) tanks with a diameter of $2.7 \mathrm{~m}$, height $1.0 \mathrm{~m}$, and filled with $5 \mathrm{~m}^{3}$ of filtered sea water were used in the study. Yellowfin tuna juveniles with an average total length of $29.82 \pm 2.51 \mathrm{~mm}$ were harvested from a hatchery and placed into each tank at a density of 50 fish tank ${ }^{-1}$. The treatments applied were two nursery systems: (A) indoor and (B) outdoor system with three replicates. The rearing treatment lasted for 21 days. Raw fish was given as feed consisting of mixed of defrosted milkfish fry and small anchovy with total length ranged between 15-25 mm as well as minced fish meat. Feed was given six times per day at satiation. The observed parameters were temperature, dissolved oxygen, and light intensity measured daily. The results showed that the survival rate of juvenile in the indoor system was $20.0 \pm 4.0 \%$ which was higher $(P<0.05)$

\footnotetext{
\# Korespondensi: Balai Besar Riset Budidaya Laut dan

Penyuluhan Perikanan

Jl. Br. Gondol, Kec. Gerokgak Kab. Buleleng, Po. Box 140,

Singaraja, Bali 81101, Indonesia

Tel. + 6236292278

E-mail: hutapeaharianto@gmail.com
} 
than that of the outdoor system $(6.7 \pm 5.0 \%$. Weight specific growth rate of fish reared in the indoor system was $12.4 \%$ day $^{-1}$ which was better than that of the outdoor system which was only $9.8 \%$ day ${ }^{-1}$ $(\mathrm{P}<0.05)$. This research concludes that a stable light intensity and water temperature in the indoor nursery system gives better survival and growth rate on yellowfin tuna juvenile. Nevertheless, this research recommends that the nursery phase of yellowfin tuna juvenile in FRP tank should be carried out not more than two weeks in order to produce a higher survival rate and then transferred to floating net cages.

\section{KEYWORDS: yellowfin tuna; juvenile; nursery; light intensity; indoor; outdoor}

\section{PENDAHULUAN}

Teknologi pembenihan ikan tuna sirip kuning telah berhasil dikembangkan di Balai Besar Riset Budidaya Laut dan Penyuluhan Perikanan (BBRBLPP) (Hutapea et al., 2007a; 2007b; Gunawan \& Hutapea, 2020; Hutapea et al., 2019). Namun, mortalitas benih yang tinggi pada pendederan masih menjadi kendala. Sama halnya pada benih tuna sirip biru Pasifik (PBT) Thunnus orientalis, mortalitas yang tinggi karena perkembangan fungsi mata lebih lambat dibandingkan perkembangan kecepatan berenang (Matsumoto et al., 2011). Produksi benih tuna-sirip biru Atlantik (ABT) Thunnus thynnus, di Uni Eropa juga menghadapi kendala yang sama sehingga sintasan benih pada umur 30 hari setelah menetas paling tinggi 0,44\%(Beijnen, 2017).

Ikan tuna sebagai spesies yang bergantung pada penglihatan (visually dependent species) sehingga faktor cahaya dapat menyebabkan stres (Matsumoto et al., 2011). Selain itu, sifat alami ikan tuna berburu ikanikan di sekitarnya dengan kecepatan berenang yang tinggi, sangat berisiko ketika berada dalam wadah yang terbatas. Ketika upaya menangkap mangsa meleset, hampir dapat dipastikan benih akan menabrak dinding bak atau jaring. Kematian bisa seketika, atau kerusakan pada bagian mulut yang menyebabkan stres, tidak mampu menangkap mangsa, dan akhirnya mati. Oleh karena itu, sistem pendederan benih ikan tuna sirip kuning dalam sistem indoor dan outdoor perlu diuji untuk mendapatkan perbaikan dalam pendederan. Tujuan riset adalah menguji sistem indoor dan outdoor pada pendederan benih ikan tuna sirip kuning untuk meningkatkan pertumbuhan dan sintasan.

\section{BAHAN DAN METODE}

Benih ikan tuna sirip kuning berumur 25 hari setelah menetas (D-25) hasil produksi hatchery, dipanen dan diseleksi. Hanya benih yang bentuk morfologinya sempurna dan berukuran relatif seragam yang digunakan dalam riset ini.

Pendederan dilakukan di dalam enam buah bak fiberglass reinforced plastic (FRP) berdiameter 2,7 $\mathrm{m}$ dan ketinggian 1,0 m dengan volume $5 \mathrm{~m}^{3}$ (Gambar 1). Penempatan bak sesuai perlakuan, tiga unit bak ditempatkan dalam ruangan (indoor), pada setiap bak dipasang satu unit lampu TL 40 watt, digantung pada bagian tengah bak dan $70 \mathrm{~cm}$ di atas permukaan bak.
Lampu dihidupkan secara terus-menerus untuk mengurangi kaget dan stres pada benih. Tiga unit bak lainnya ditempatkan di luar ruangan (outdoor). Untuk mengurangi intensitas cahaya matahari yang masuk ke dalam bak, paranet dengan kerapatan $60 \%$ dipasang di atas lokasi riset dengan ketinggian 1,5 m dari permukaan bak.

Empat buah batu aerasi dipasang di dekat dasar dinding bak dengan jarak yang sama antar aerasi. Air laut yang digunakan telah melewati high pressure sand filter (HPSF). Pada masing-masing bak dipasang pipa PVC 1 inci secara vertikal di dinding bak dan setiap 5 $\mathrm{cm}$ dibuat lubang dengan diameter $3 \mathrm{~mm}$ yang sejajar dinding bak. Untuk mengatur kecepatan/debit air, setiap pipa pemasukan air dipasang satu stop keran yang dibuka sesuai dengan kebutuhan dan putaran air berlawanan arah jarum jam sesuai gaya Coriolis pada belahan bumi selatan. Pembuangan air dilakukan pada bagian tengah-dasar bak.

Hewan uji berupa benih ikan tuna sirip kuning hasil produksi dari hatchery, diisi sebanyak 50 ekor per bak dengan panjang total rata rata 29,82 $\pm 2,51 \mathrm{~mm}$ dan bobot tubuh 0,32 $\pm 0,08 \mathrm{~g}$ (Gambar 2).

Perlakuan yang diterapkan adalah perbedaan sistem pemeliharaan, yaitu: (A) indoor dan (B) outdoor dengan tiga ulangan. Riset dilakukan selama 21 hari. Pakan yang digunakan berupa ikan segar, baik berupa benih bandeng yang dimatikan dan ikan teri, keduanya dengan panjang total berkisar antara $15-25 \mathrm{~mm}$ dan ikan cincang (minced fish) dengan frekuensi pemberian enam kali per hari dan diberikan secara satiasi.

Penghitungan sintasan dilakukan setiap hari yaitu dengan menghitung benih yang mati. Untuk parameter pertumbuhan, setiap tujuh hari dilakukan pengukuran dan penimbangan benih yang mati akibat menabrak dinding, yang kondisinya masih segar dan tidak kurus (Gambar 3).

Parameter yang diamati adalah tingkah laku benih, pertumbuhan, dan sintasan benih selama pemeliharaan. Analisis pertumbuhan dengan menggunakan rumus specific growth rate (SGR) (Boyer et al., 1994):

$$
\mathrm{SGR}=\left[\left(\frac{\ln W \mathrm{t}-\ln W_{0}}{\mathrm{t}}\right)\right] \times 100
$$




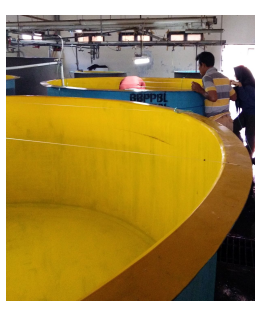

A

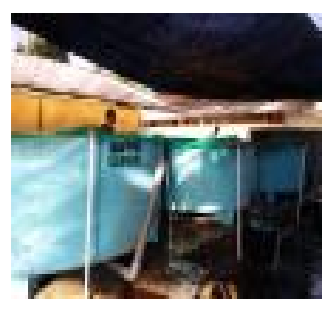

B

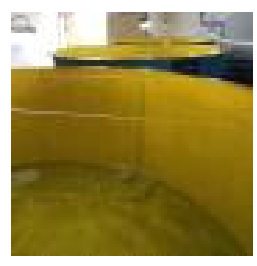

C

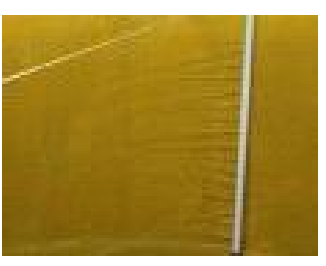

D

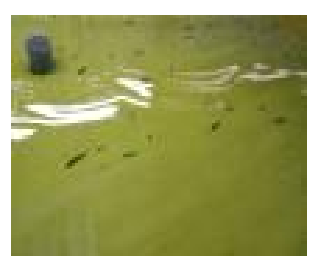

$E$

Gambar 1. Wadah penelitian berupa tiga buah bak fiberglass reinforced plastic untuk sistem indoor (A) dan tiga buah untuk sistem outdoor (B); aerasi di dasar bak dekat dinding (C); air masuk ada sisi bak melalui pipa pralon yang dilubangi (D), dan air keluar di dasar tengah bak (E).

Figure 1. Fiberglass reinforced plastic tanks (FRP) used in the experiment for the indoor system (A) and outdoor system (B); aeration system positioned at the bottom near the side wall (C); water inlet at the side wall (D), and water outlet at the bottom-center of tank (E).

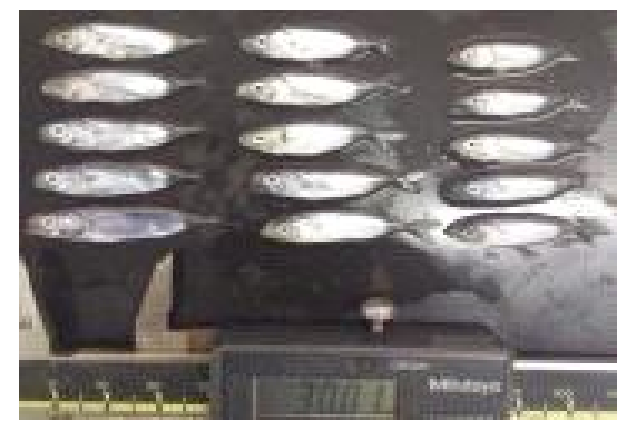

Gambar 2. Ukuran benih ikan tuna sirip kuning, Thunnus albacares yang diseleksi dan digunakan sebagai hewan uji dalam pendederan sistem indoor dan outdoor.

Figure 2. The average size of yellowfin tuna, Thunnus albacares juveniles used the study.

di mana:

$W_{0}$ : rata rata bobot tubuh awal $(\mathrm{g})$

$\mathrm{W}_{\mathrm{t}}$ : rata rata bobot tubuh akhir penelitian $(\mathrm{g})$

t : lama pemeliharaan (hari)

Faktor kondisi dihitung menggunakan rumus (Ricker, 1958 dalam Sharma \& Bhat, 2015) yaitu:

$$
C F=\left(\frac{W}{L^{2}}\right) \times 100
$$

di mana:

CF : condition factor

W : bobot tubuh $(\mathrm{g})$

$\mathrm{L} \quad$ : panjang total $(\mathrm{cm})$
Data sintasan dan pertumbuhan dianalisis dengan uji T, sedangkan tingkah laku benih dianalisis secara deskriptif.

\section{HASIL DAN BAHASAN}

\section{Aklimatisasi Benih}

Benih ikan tuna yang dipanen dari hatchery dimasukkan ke masing-masing bak penelitian, diberi pakan berupa larva ikan bandeng. Benih pada sistem indoor langsung beradaptasi dengan membentuk kelompok dan merespons pakan yang diberikan. Sebaliknya, benih dalam sistem outdoor masih berpencar dan belum aktif mencari pakan. Ini 


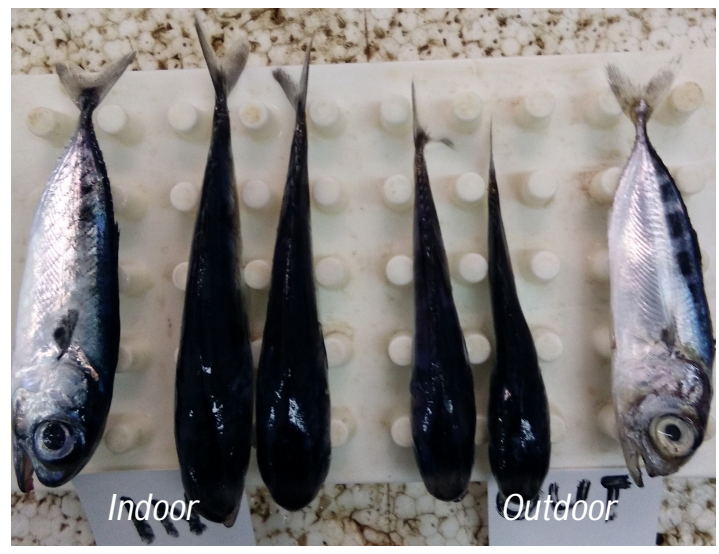

Gambar 3. Perbandingan morfometrik ikan sampel indoor dan outdoor yang diukur dan ditimbang setiap tujuh hari.

Figure 3. Morphometric comparison of sampled fish from indoor and outdoor systems measured and weighed every seven days

menunjukkan bahwa pemindahan benih dari hatchery ke bak pendederan memberikan dampak stres yang lebih besar pada sistem outdoor dibandingkan sistem indoor.

Kematian hewan uji yang terjadi pada beberapa hari pertama berkaitan dengan stres saat panen dari hatchery dan pemindahan ke bak-bak riset. Sebagaimana dilaporkan Higuchi et al. (2014) bahwa kematian benih PBT pada 1-3 hari awal transportasi berkaitan dengan stres fisiologis akibat pemindahan. Tidak ada kematian selama lima hari kemudian menunjukkan bahwa benih telah beradaptasi. Namun hari-hari berikutnya kematian benih kembali terjadi dengan kondisi mata yang berdarah atau bengkak dan observasi internal menunjukkan ada tulang vertebrata yang patah, sehingga kematian benih diperkirakan akibat menabrak dinding bak. Memang larva stadia post flexion dan benih stadia awal mengalami perkembangan kemampuan mencari pakan yang pesat, berarti tidak rentan terhadap kematian akibat kelaparan (Margulies et al., 2007), dengan kata lain kematian lebih oleh karena menabrak dinding bak. Sebenarnya jumlah pakan yang diberikan lebih dari cukup, yaitu 40-60 g/bak atau setara dengan 100\%160\% biomassa per hari yang dibagi menjadi enam kali pemberian pakan.

\section{Kebiasaan Berenang dan Pemangsaan}

Pagi hari biasanya benih ikan tuna lebih aktif dan berenang ke segala arah untuk mencari pakan dan bergerak ke arah permukaan air dalam kelompok ketika akan diberi pakan. Ketika pakan diberikan, benih berebut dan bahkan ada yang sampai melompat keluar permukaan air. Setelah kenyang benih yang sehat berenang dalam kelompok dan berlawanan arah arus mengelilingi bak, tetapi benih yang kurang sehat biasanya berenang tidak beraturan. Menurut Sakamoto et al. (2007), pada benih ikan PBT, sifat bergerombol ini hanya terjadi pada siang hari. Hal ini terkait dengan sifat ikan tuna yang mengandalkan penglihatan.

Benih ikan tuna sirip kuning sangat sensitif terhadap perubahan lingkungan baik cahaya, gerakan terlebih terhadap suara. Kelemahan dalam sistem outdoor terletak pada cahaya yang bisa berubah secara cepat, dan adanya organisme pengganggu seperti burung atau serangga dan orang yang mendekat ke bak pemeliharaan dapat menyebabkan benih kaget dan berenang tidak beraturan dan menabrak dinding. Hal ini terjadi pada benih umur 25-40 hari setelah menetas yang berhubungan dengan ketidakseimbangan antara perkembangan penglihatan dengan kemampuan berenang (Sakamoto et al., 2007). Sebaliknya benih dalam sistem indoor lebih tenang karena cahaya yang berasal dari lampu TL tidak berubah-ubah dan intensitasnya lebih rendah dan tidak banyak gangguan dari organisme di sekitar bak. Benih menjadi lebih tenang dan berenang lebih teratur dalam lingkaran. Kebiasaan benih ikan tuna dalam menangkap mangsa, kalau yang diberikan berupa benih bandeng yang dimatikan atau ikan teri ukuran panjang total 15-25 $\mathrm{mm}$, pasti ditangkap dari samping dan kemudian dilepas agar bagian kepala pakan diarahkan ke bagian mulut untuk ditelan. Hal ini menunjukkan bahwa sifat alaminya masih terlihat, seolah-olah pakan yang diberikan masih hidup sehingga ditangkap pada bagian tengah tubuh. Lain halnya ketika diberi potongan ikan, ditangkap dan kemudian langsung ditelan. Kebiasaan pemangsaan lainnya yaitu benih ikan tuna hanya akan berusaha menangkap pakan mulai dari permukaan air sampai pertengahan kolom air. Ketika pakan sudah 
mendekati dasar bak, tidak akan dicari lagi. Oleh karena itu, semakin tinggi kedalaman air pemeliharaan, semakin besar kesempatan benih untuk memangsa pakan atau pemberian pakan harus dilakukan sedikit demi sedikit.

\section{Parameter Lingkungan Pendederan}

Berdasarkan pengukuran intensitas cahaya di bawah jaring penutup, oksigen terlarut dan suhu pada siang hari, pada sistem indoor dan sistem outdoor (Tabel 1), faktor intensitas cahaya dan fluktuasi suhu yang lebih tinggi pada sistem outdoor berdampak terhadap sintasan dan pertumbuhan. Cahaya matahari tidak hanya menyebabkan intensitas cahaya lebih tinggi tetapi juga mentransfer panas ke dalam media air sehingga suhu terendah pada siang hari selalu lebih tinggi di sistem outdoor Pada sistem indoor dengan menggunakan lampu TL, tidak terjadi transfer panas, sedangkan penyinaran yang stabil dan kontinu dapat mengurangi stres. Memang ada beberapa pendapat yang masih kontradiksi, Filgueira (2009) menyatakan pencahayaan secara terus-menerus hingga umur 20 hari dan menjadi 12 jam terang: 12 jam gelap dan cahaya alami pada stadia berikutnya. Sebaliknya Ishibashi et al. (2013a) mengatakan bahwa pencahayaan 24 jam dengan intensitas cahaya $\geq 150$ lux efektif dalam menurunkan mortalitas benih PBT dalam budidaya. Awal metamorfosa benih PBT mempunyai penglihatan scotopic (scotopic vision) yang perkembangannya jauh lebih lambat dibandingkan dengan benih ikan laut lainnya (Ishibashi et al., 2009) sehingga kemampuan melihat dalam gelap belum sempurna, maka sering menabrak dinding bak pada malam hari. Lebih detail Masuma et al. (2001) menyatakan bahwa juvenil tuna sirip biru dengan panjang total 50,7-96,8 mm; transisi penglihatan dari scotopic ke photopic terjadi pada intensitas cahaya 7,52 lux dan diperlukan waktu 15 menit untuk menyesuaikan. Pengamatan pada sistem outdoor menunjukkan bahwa pada waktu subuh (fajar menyingsing), intensitas cahaya dari tingkat scotopic ke tingkat photopic sangat cepat dan tercapai hanya dalam 10 menit. Ketidakmampuan adaptasi retina terhadap perubahan intensitas cahaya tersebut dapat menyebabkan disorientasi penglihatan sehingga tidak dapat mengontrol kecepatan berenang dan kemudian menabrak dinding.

Debit air diatur sesuai pertumbuhan benih, yaitu 0,2-0,4 $\mathrm{L} \mathrm{det}^{-1}$ yang setara dengan pergantian air 750$1.200 \%$ hari $^{-1}$ atau kecepatan arus 55-110 mm det-1, telah mampu membangun sistem vortex, hampir sama dengan yang digunakan Biswas (2010) yaitu 0,5 L $\operatorname{det}^{-1}$. Kematian benih kembali meningkat satu minggu setelah penebaran. Dibutuhkan arus yang lebih tinggi sejalan dengan pertumbuhan benih, namun karena aliran air hanya mengandalkan sistem gravitasi sehingga tidak dapat ditingkatkan. Berdasarkan penelitian Sabate et al. (2012) ada dua pendekatan kebutuhan kecepatan arus dalam pemeliharaan benih ikan tuna yaitu batas relatif kecepatan berenang (relative critical swimming speed (RCSS)) yaitu ketahanan benih terhadap kecepatan arus tertentu yang dinaikkan secara bertahap yang berkisar antara 4,7-20,3 SL det${ }^{1}$ dan ketahanan maksimum pada kecepatan tertentu (maximum sustainable swimming speed (MSSS) sebagai kecepatan maksimum benih yang masih dapat bertahan pada $4 \mathrm{SL}$ det $^{-1}$. Dalam riset ini kecepatan arus yang diterapkan hanya 0,68-1,16 SL det-1; masih sangat rendah dan mungkin ini yang menyebabkan tingginya kematian akibat menabrak dinding bak.

Tabel 1. Parameter lingkungan yang diukur pada pendederan benih ikan tuna, Thunnus albacares dalam sistem indoor dan outdoor

Tabel 1. Environmental parameters measured during the nursery experiment of yellow fin tuna Thunnus albacares in indoor and outdoor systems

\begin{tabular}{lccc}
\hline \multicolumn{1}{c}{$\begin{array}{c}\text { Parameter } \\
\text { Param eter }\end{array}$} & $\begin{array}{c}\text { Posisi (waktu) } \\
\text { Position (time) }\end{array}$ & $\begin{array}{c}\text { Indoor } \\
\text { (24 L) }\end{array}$ & $\begin{array}{c}\text { Outdoor } \\
\text { (12 L:12 D) }\end{array}$ \\
\hline Intensitas cahaya & Atas (Above the net) & $650-920$ & $15.000-29.000$ \\
Light intensity (Lux) & Bawah (Below the net) & $220-430$ & $360-1100$ \\
\hline Suhu & Pagi (Morning ) & $26,9-27,3$ & $26,6-27,1$ \\
Temperature $\left({ }^{\circ} \mathrm{C}\right)$ & Siang (Afternoon) & $27,2-27,8$ & $27,5-27,8$ \\
\hline Oksigen terlarut & Pagi (Morning ) & $7,61-8,13$ & $7,62-8,13$ \\
Dissolved oxygen $\left(\mathrm{mg} \mathrm{L} \mathrm{L}^{-1}\right)$ & Siang (Afternoon ) & $7,30-8,31$ & $7,46-8,41$ \\
\hline Pergantian air & Air mengalir & $0,2-0,4$ \\
Water exchange (L det $\left.{ }^{-1}\right)$ & Flow through system & $0,2-0,4$ & 0 \\
\hline
\end{tabular}




\section{Sintasan Benih}

Mortalitas terjadi pada benih yang tidak mampu beradaptasi terhadap lingkungan yang baru, faktor eksternal seperti adanya perubahan cuaca yang tibatiba dapat menyebabkan stres, dan faktor internal berupa kemampuan berenang benih yang meningkat pesat sehingga sering menabrak dinding bak.

Sintasan benih hingga hari ke-10, pada sistem indoor $66,00 \pm 1,63 \%$ masih lebih baik daripada sistem outdoor yang hanya $56 \pm 5,89 \%$ Demikian juga pada akhir penelitian (21 hari), pada sistem indoor $(20,00$ $\pm 3,27 \%$ lebih baik dibandingkan dengan sistem outdoor yang hanya $6,7 \pm 4,11 \%(P<0,05)$ (Gambar 4$)$.

Memasuki stadia benih, ABT mengalami perubahan sosial yaitu mulai bergerombol dan setelah bergerombol, kanibalisme mulai menurun (Beijnen, 2017) dan ini merupakan sifat ikan tuna pada umumnya. Kondisi lingkungan juga dapat menurunkan sifat kanibalisme, seperti bentuk bak, intensitas cahaya, kepadatan benih, serta penyortiran berdasarkan ukuran secara regular. Bahkan, Ishibashi et al. (2013b) mengatakan bahwa sintasan benih ikan tuna lebih tinggi dalam bak dengan dinding bercorak polkadot atau kotak-kotak, sayangnya pendederan ini hanya sembilan hari sehingga belum dapat digunakan sebagai standar.

\section{Pertumbuhan Benih}

Hasil penelitian benih ikan tuna dalam 21 hari (Gambar 5 dan 6). Pertumbuhan panjang total dan bobot tubuh benih pada sistem indoor lebih tinggi dibandingkan dengan sistem outdoor.
Benih tumbuh dari rata rata panjang total awal $29,82 \pm 2,51 \mathrm{~mm}$ dan bobot awal 0,32 $\pm 0,08 \mathrm{~g}$; menjadi $83,13 \pm 5,48 \mathrm{~mm}$ dan $6,97 \pm 1,87 \mathrm{~g}$ pada sistem indoor, sementara pada sistem outdoor berturutturut menjadi 72,03 $\pm 2,92 \mathrm{~mm}$ dan 4,24 $\pm 0,53 \mathrm{~g}$.

Faktor kondisi (condition factor (CF)) benih ikan tuna dalam pemeliharaan indoor $(1,19 \pm 0,12)$ sedangkan dalam pemeliharaan outdoor $(1,14 \pm 0,18)$, namun berdasarkan analisis statistik tidak berbeda nyata. Berarti ada kecenderungan pertambahan bobot per satuan pertambahan panjang benih pada perlakuan indoor lebih tinggi. Nilai CF lebih dari satu, menunjukkan bahwa benih pada kedua perlakuan bertumbuh dengan baik (Datta et al., 2013).

Pola pertumbuhan benih pada kedua sistem ini relatif sama, namun laju pertumbuhan spesifik pada sistem indoor $12,4 \pm 1,82 \%$ hhari lebih tinggi $(P<0,05)$ dibandingkan dengan sistem outdoor dengan nilai hanya $9,87 \pm 0,05 \%$ hari. Laju pertumbuhan spesifik untuk bobot tubuh benih ikan tuna sirip kuning pada sistem indoor tertinggi terjadi pada minggu pertama, sedangkan pada sistem outdoor pada minggu kedua, kemudian menurun hingga akhir penelitian (Gambar 7). Perbedaan ini berkaitan dengan kemampuan adaptasi dan keaktifan benih memangsa pakan yang diberikan yang jauh lebih baik pada sistem indoor dibandingkan dengan benih dalam sistem outdoor.

Pertambahan bobot benih dari awal hingga akhir penelitian sebesar $2.178 \pm 693 \%$ pada sistem indoor, jauh lebih tinggi dan berbeda nyata $(P<0,05)$ dibandingkan dengan pada sistem outdoor yang hanya mencapai $1.244 \pm 550 \%$ Nilai ini jauh lebih tinggi

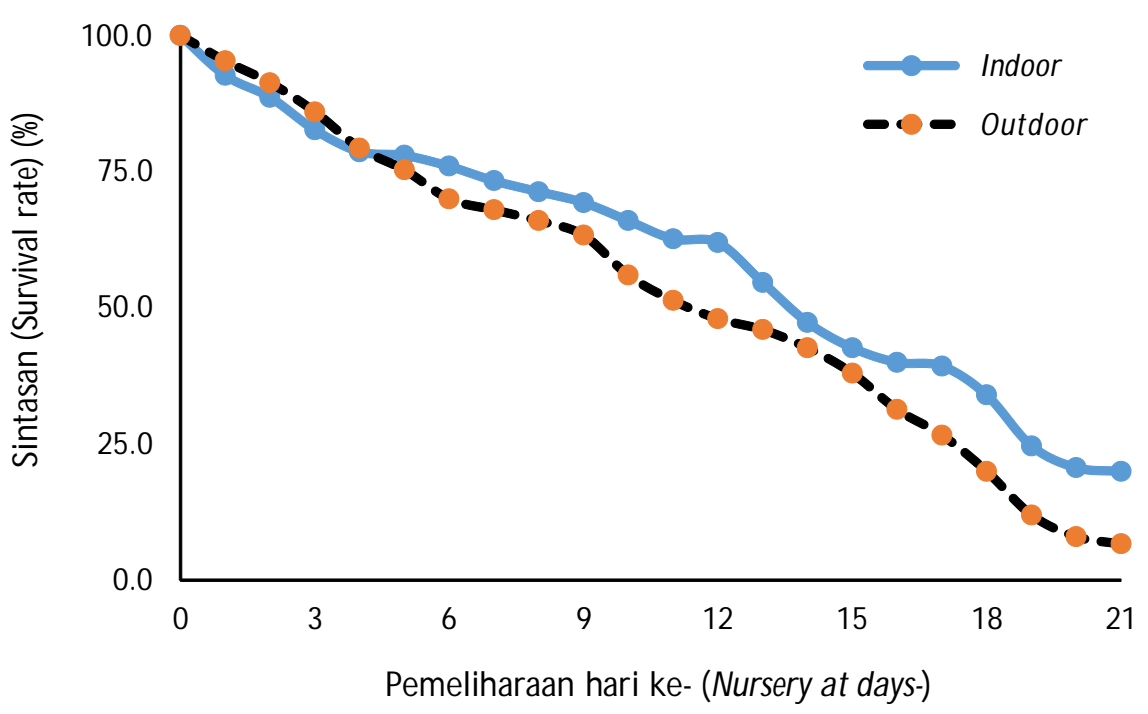

Gambar 4. Sintasan benih ikan tuna sirip kuning dalam pendederan dengan sistem indoor dan outdoor.

Figure 4. Survival rate of yellowfin tuna juveniles in indoor and outdoor nursery systems. 


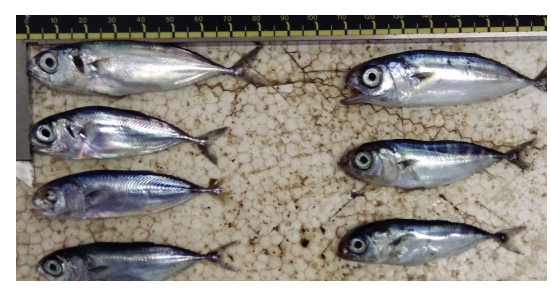

Indoor
Outdoor

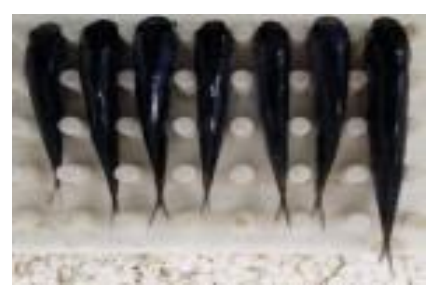

B

Gambar 5. Benih ikan tuna sirip kuning yang ditimbang setiap tujuh hari dalam riset pendederan dengan sistem indoor (IND) dan outdoor (OUTD) (A); dan kondisi benih yang gemuk dari kedua perlakuan yang digunakan sebagai contoh (B).

Figure 5. Yellowfin tuna juveniles measured every seven days during the nursery period in indoor (IND) and outdoor (OUTD) (A); and fat juveniles from both treatments were used as samples (B).

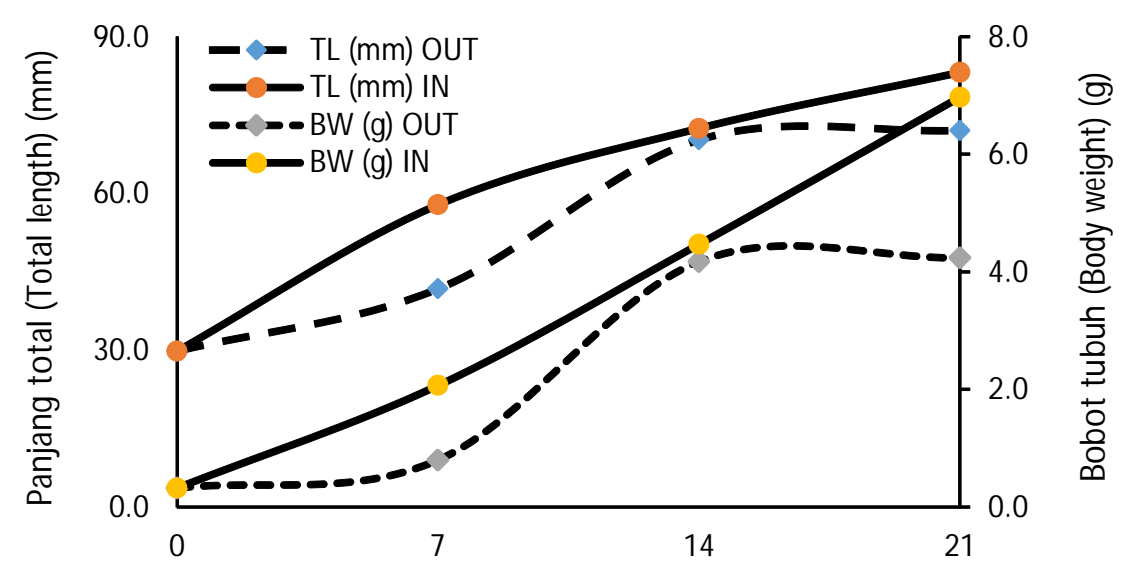

Pemeliharaan hari ke- (Nursery at days-)

Gambar 6. Pertumbuhan panjang total dan bobot tubuh benih ikan tuna yang dipelihara dalam sistem indoor dan outdoor.

Figure 6. Total length and body weight gain of yellowfin tuna juveniles reared in indoor and outdoor systems during the experiment.

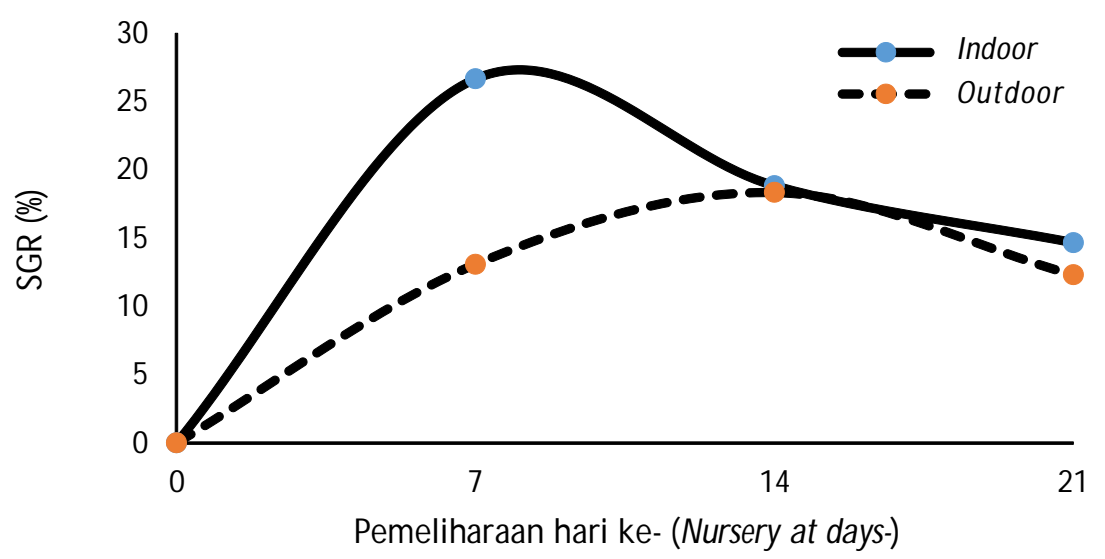

Gambar 7. Pertumbuhan spesifik (SGR) benih ikan tuna sirip kuning yang dipelihara selama 21 hari dalam sistem indoor dan outdoor.

Figure 7. Specific growth rate of yellowfin tuna juvenile during 21 days of nursery in indoor and outdoor systems. 
dibandingkan dengan yang diperoleh Biswas (2010) yaitu antara $600 \% 800 \%$ dalam 10 hari penelitian.

\section{KESIMPULAN}

Sintasan akhir pendederan benih ikan tuna sirip kuning pada sistem indoor dalam bak fiberglass reinforced plastic berdiameter 2,7 m; ketinggian 1,0 m; dan volume $5 \mathrm{~m}^{3}$; sebesar $20,0 \%$ lebih tinggi dibanding dengan sistem outdoor yang hanya 6,7\% Pertumbuhan spesifik benih ikan tuna sirip kuning pada sistem indoor $12,4 \%$ hari; lebih tinggi pada sistem indoor dibandingkan sistem outdoor yang hanya 9,8\% hari.

\section{UCAPAN TERIMA KASIH}

Riset ini terlaksana atas dana Anggaran Pendapatan Belanja Negara (APBN) 2019 dan atas bantuan teknisi Muhammad Arif, Sahrody, Slamet Haryadi, dan I Nengah Mupu mulai dari pemeliharaan larva hingga pelaksanaan riset ini, baik dalam pemberian pakan, penyiponan dan pengukuran parameter lingkungan, diucapkan terima kasih.

\section{DAFTAR ACUAN}

Beijnen, van J. (2017). The closed cycle aquaculture of Atlantic bluefin tuna in Europe. Current status, market perceptions and future perspectives. DOI: 10.13140/RG.2.2.14033.53601. Fish Physiol. Biochem., 95 pp. https://doi.org/10.1007/s10695018-0587-9, diunduh pada 3 Januari 2019.

Biswas, B.K. (2010). Establishment of formulated diet for rearing juvenile bluefin tuna, Thunnus orientalis. Bull. Fish. Lab. Kinki. Univ., 12, 17-129.

Boyer, N.J., Van Toever, W., \& Jansen, M.E. (1994). Effect of photoperiod on growth of Arctic charr under commercial production conditions. Prog. Fish-Cult., 56, 44-46.

Datta, S.N., Kaur, F.I., Dhawan, A., \& Jassal, G. (2013). Estimation of length-weight relationship and condition factor of spotted snakehead Channa punctata (Bloch) under different feeding regimes. SpringerPlus. http://www.springerplus.com, diunduh pada 12 Maret 2020.

Filgueira, F.J.R. (2009). Improvements in the production technology of red porgy (Pagrus pagrus) larvae and fry: Importance of rearing conditions and diet nutritional value on their quality. Thesis Doctoral. Universidad De Las Palmas De Gran Canaria. Departamento de Biologìa. 371 pp.

Gunawan \& Hutapea, J.H. (2020). Perbedaan waktu awal pemberian larva ikan sebagai pakan dalam pemeliharaan larva ikan tuna sirip kuning Thunnus albacares. Journal of Fisheries and Marine Research, 04(1), 135-143.

Higuchi, K., Tanaka, Y., Eba, T., Nishi, A., Kumon, K., Nikaido, H., \& Shiozawa, S. (2014). Causes of heavy mortality of hatchery-reared Pacific bluefin tuna Thunnus orientalis juveniles in sea cages. J. Aquaculture, 424-425, 140-145.

Hutapea, J.H., Permana, I G.N., \& Andamari, R. (2007a). Perkembangan embrio ikan tuna sirip kuning (Thunnus albacares). J. Ris. Akuakultur, 2(1), 9-14.

Hutapea, J.H., Permana, I G.N., \& Andamari, R. (2007b). Pengaruh salinitas terhadap sintasan larva stadia awal ikan tuna sirip kuning (Thunnus albacares). Pengembangan Teknologi Budidaya Perikanan. hlm. 127-131.

Hutapea, J.H., Gunawan, Setiadi, S., \& Slamet, B. (2019). The inner wall of the tank painted in black is good for larval rearing of yellowfin tuna Thunnus albacares. Aquacultura Indonesiana, 20(2),:46-52.

Ishibashi, Y., Honryo, T., Saidaa, K., Hagiwaraa, A., Miyashita, S., Sawada, Y., Okada, T., \& Kurata, M. (2009). Artificial lighting prevents high night-time mortality of juvenile Pacific bluefin tuna, Thunnus orientalis, caused by poor scotopic vision. J. Aquaculture, 293(3-4), 157-163.

Ishibashi, Y., Honryo, T., Miyashita, S., \& Oda, S. (2013a). Suitable photoperiod and light intensity of laboratory-reared juvenile pacific bluefin tuna Thunnus orientalis. Short Paper: Journal Free Access, 61(4), 399-402.

Ishibashi, Y., Izumi, T., Kurata, M., \& Okada, T. (2013b). Effects of tank wall pattern on survival, bone injury rate, and stress response of juvenile Pacific bluefin tuna, Thunnus orientalis. Aquacultural Engineering, 56(September 2013), 13-17.

Margulies, D., Scholey, V.P., Wexler, J.B., Olson, R.J., Suter, J.M., \& Hunt, S.L. (2007). Inter-American Tropical Tuna Commision: A review of IATTC research on the early life history and reproductive biology of scombrids conducted at the Achotines Laboratory from 1985 to 2005. 67 pp.

Masuma, S., Kawamura, G., Tezuka, N., Koiso, M., \& Namba, K. (2001). Retinomotor response of juvenile bluefin tuna Thunnus thynnus. Fisheries Science, 67(2), 228-231.

Matsumoto, T., Okada, T., Sawada, Y., \& Ishibashi, Y. (2011). Changes in the scotopic vision of juvenile Pacific bluefin tuna (Thunnus orientalis) with growth. Fish Physiology and Biochemistry, 37(3), 693-700. 
Sabate, F. de la S., Nakagawa, Y., Nasu, T., Sakamoto. W., \& Miyashita, S. (2012). Critical swimming speed and maximum sustainable swimming speed of juvenile Pacific bluefin tuna, Thunnus orientalis. Aquacult. Int., 21, 177-181.

Sakamoto, W., Yamane, T., Takagi, T., Mitsunaga, Y., Torisawa, S., Takashi, T., Suzuki, K., ....., \& Fukuda, H. (2007). Chapter 2. Environmental science for aquaculture-2. (9 pp.). Center for Aquaculture Science and Technology for Bluefin Tuna and Other
Cultivated Fish. Kinky University, 21 st Century COE Program Final Report: 2003-2007. Diunduh 7 Desember 2020 pada https://www.flku.jp/coe/ finalreport/index.html.

Sharma, R.K. \& Bhat, R.A. (2015). Length-weight relationship, condition factor of rainbow trout (Oncorhynchus mykiss) from Kashmir waters. Annals of Biological Research, Scholars Research Library. 6(8), 25-29. 